\title{
Всеукраїнська школа неврологів: стратегія 2017 року
}

\section{Свиридова Н.}

д.мед.н., професор, завідувач кафедри неврології і рефлексотерапії

Національної медичної академії післядипломної освіти імені П.Л. Шупика

Резюме. Школа неврологів надає унікальну можливість лікарям багатьох спеціальностей почерпнути нові знання, досвід, ознайомитись з новинками в сфері діагностики та лікування різноманітних захворювань, в тому числі і в неврології.

Створена школа неврологів за допомогою «Всеукраїнської асоціащії по неврології та рефлексотерапії» під керівництвом Свиридової Наталії Костянтинівни, яка започаткувала проведення різних майстер-класів тренінгів з міжнародною участю.

Практичні заняття проводять висококваліфіковані спеціалісти, талановиті молоді вчені, а також іноземні доповідачі. На кожній школі неврологів присутні більше 100 лікарів різних спеціальностей зі всієї Украӥни.

Ключові слова: школа неврологів, неврологія, тренінг, майстер-клас, підвищення кваліфікаціiі

\section{8-29 січня 2017 р. «Хронічна ішемія мозку та екстрапірамідні розлади. Хвороба Паркінсона»}

Буде можливість переглянути основні аспекти та нові дані про хронічну ішемію мозку, специфічні характеристики та особливості тактики лікування, а також забезпечення об'єктивізації постановки діагнозу за допомогою шкал та опитувальників. Підкреслення важливих моментів у клінічній картині, тактиці лікування хвороби Паркінсона. Буде йти мова про експрес-діагностику хвороби Паркінсона. Не мало важливим буде розгляд проблеми постановки діагнозу судинний паркінсонізм. Особливості діагностики та диференційної діагностики 3 іншими захворюваннями, які проявляються брадикінезією тремором та м'язовою ригідністю. Ознайомлення 3 всіма можливими екстрапірамідними розладами: тремор, міоклонус, тік, дистонія, хорея, та їх особливостями діагностики та лікування. На закріплення знань будуть показані клінічні випадки даних захворювань.

\section{5-26 лютого 2017 р. «Біль в спині. Радикуліт. Тривога депресія порушення сну»} Буде розглянуто найчастіші причини візитів до лікарів багатьох спеціальностей такі як болі в спині, порушення сну, відчуття тривоги. Постане можливість продиференціювати радикулярний біль від специфічного болю при пухлинах та туберкульозному процесі. Буде зроблено акцент на методах діагностики та лікування дегенеративно-дистрофічних захворювань хребта. Отримаєте неоціненний досвід від європейських колег 3 Великої Британії про оцінку набряку диску зорового нерву при розвитку головного болю. Дізнаєтесь що таке нейропатичний біль, його основи патогенезу та правильної тактики діагностики i лікування. Побуваєте на майстер-класі по тактиці проведення блокад при болях у шийному та поперековому відділах хребта. Можливості діагностики прихованої депресії і як саме 3 нею боротись.

\section{5-26 березня 2017 р. «Транзиторна ішемічна атака. Когнітивні порушення. Деменція»}

Розглядатимуться питання швидкої діагностики та диференційної діагностики транзиторної ішемічної атаки. Обговорюватимуться питання діагностики когнітивних порушень за допомогою MMSE та МоСа тестів. Отримаєте можливість прослухати доповідь канадських вчених про основні принципи діагностики та лікування хвороби Паркінсона. Також поговоримо про досить часту скаргу пацієнтів - запаморочення. Яке відношення 
головокружіння має до когнітивних порушень. Одним з важливих питань постане виявлення ознак деменції та завчасне іiі лікування. Почерпнете напрацьований досвід в області методів обстеження в неврології, а саме: електроенцефалографії (ЕЕГ) як додатковому методі діагностики когнітивних порушень.

\section{2-23 квітня 2017 р. «Шшемічний інсульт. Геморагічний інсульт»}

Тема присвячена особливостям диференційної діагностики ішемічного та геморогічного інсультів. Детально буде розглянуто підтипи та варіанти перебігу інсультів. Застосування електроенцефалографії для діагностики гострого порушення мозкового кровообігу. Зв'язок інсульту 3 подальшим розвитком когнітивних порушень. Читатиметься доповідь про незрозумілу втрату зору колегами з Великої Британії.

\section{7-28 травня 2017 р. «Гострий біль. Цервікалгії. Цервікокраніалгії. Неврастенія, інсомнія»}

Будуть розглянуті основні аспекти діагностики захворювань переферичної нервової системи. Диференційна діагностика мононевропатій, полінейропатій, множинних невропатій, радикулопатій та плексопатій. Постане питання дифенціювання рефлекторних больових феноменів від дискогенного болю шийного та поперекового відділів хребта. Прослухаєте цікаву доповідь американських вчених про виникнення болю при інсультах. Розглянете діагностичний алгоритм гострого та хронічного болю, особливості клініки та тактики лікування. Також не менш цікава доповідь про зміни в лікворі при гострому болю. Матимете можливість удосконалити знання по техніці паравертебральних блокад в шийному відділі хребта.

24-25 червня 2017 р. «Головний біль. Мігрень. Хронічний біль. Тривога, депресія, порушення сну»

Зосередження уваги на діагностиці різних видів головного болю та правильній постановці діагнозу на прикладі клінічних випадків. Прозвучать основні критерії для діагностики мігрені, а також нові методи іiі лікування та профілактики. Виникне питання інновацій в сфері лікування тривоги та депресії. Вплив порушень сну та виникнення ускладнень з боку різних органів та систем. Дізнаєтесь нові аспекти диференційної діагностики болю з доповіді вчених США.

23-24 вересня 2017 р. «Дисциркуляторна енцефалопатія (гіпертензивна та атеросклеротична). Інсульт в вертебро-базилярному басейні»

Буде організована та проведена дискусія встрановлення діагнозу “Дисциркуляторна енцефалопатія", іiї поширеність та зв'язок з порушенням здорового способу життя. Основні принципи на яких базується постановка даного діагнозу. Розглядатимуться питання диференційної діагностики підтипів дисциркуляторної енцефалопатії, розвитку можливих ускладнень, тактики лікування та профілактики даного захворювання. Дана тематика допоможе правильно продиференціювати гостре порушення мозкового кровообігу в вертебро-базилярному басейні від інших захворювань зі схожою клінічною картиною.

28-29 жовтня 2017 р. «Синдром вегетативної дистонії. Неврастенія. Тривога. Порушення сну»

Що ж таке насправді “вегетосудинна дистонія”? Функціональний розлад чи органічна патологія? Про це та інше розкажуть спеціалісти на даній школі неврологів. Про критерії постановки діагнозу, про важливість лікування та профілактики цього стану, про можливі ускладнення. Нові аспекти в лікуванні тривоги та порушень сну. Дізнаєтесь про нові критерії діагностики та лікування панічних атак, інсомній. 
25-26 листопада 2017 р. «Інсульт та його підтипи. Ускладнення інсульту. Реабілітація після інсульту».

Детально розглянуться питання підтипів ішемічного інсульту. Не менш важливе питання виявлення постінсультної депресії під час гострої стадії інсульту, можливість іiї корекції та профілактики. Місце реабілітаційних заходів у профілактиці постінсультних ускладнень та адаптації пацієнта до життя в соціумі. Рання реабілітація - запорука швидкого одужання? Дізнайтесь відповідь на запитання на даній школі неврологів.

23-24 грудня 2017 р. «Демілінізуючі захворювання. Розсіяний склероз. Хвороба Паркінсона»

Збагатите свій досвід новими знаннями в виявленні, діагностиці та лікуванні спадкових та набутих демілінізуючих захворювань. Особливості та критерії діагностики розсіяного склерозу. Шкала EDSS як один з методів діагностики ступеня інвалідизації у пацієнтів 3 розсіяним склерозом. Розглянете сучасні аспекти лікування та профілактики загострень при розсіяному склерозі. Важливим постане питання екстрапірамідних розладів на прикладі хвороби Паркінсона. Дізнаєтесь про новітні методи лікування та можливість покращення якості життя пацієнтів з хворобою Паркінсона. 